\title{
Research on the Construction of Excellent Shared Course "The Principle and Application of Operating System"
}

\author{
Li Qiong \\ School of Computer Science and Technology \\ Hankou University \\ Wuhan, Hubei, China, 430212
}

\author{
Yan Lijuan* \\ Laboratory and Equipment Management Center \\ Hankou University \\ Wuhan, Hubei, China, 430212
}

\author{
Chen $\mathrm{Li}$ \\ School of Computer \\ Central China Normal University \\ Wuhan, Hubei, China, 430079
}

\begin{abstract}
As a basic and core curriculum in computer major, the Principle and Application of Operating System covers a wide range and develops rapidly, and its related concepts and system are also in development and improvement, which make it is hard to teach and make related studies. In order to solve this problem, this paper tries to construct the excellent shared course "The Principle and Application of Operating System", that is, using online assisted learning and offline instructions to improve the teaching effect, raise teaching quality and eventually solve the problem exists in education.
\end{abstract}

Keywords-The Principle and Application of Operating System; excellent shared course; online learning; offline instruction

\section{INTRODUCTION}

The Principle and Application of Operating System is about teaching four resource management functions in computer, including: Operating System introduction, process management, storage management, equipment management, file management and Linux application [1]. It demands students to master the basic structure of operating system, working principle and implementation strategy; comprehend the relationship between operating system and hardware/software; and construct a theoretical foundation for analyzing or designing a real operating system [2]

\section{A. Teaching objectives}

Knowledge objects: master working principle and implementation method of Operating System, including: strategy and algorithm of modern operating system to manage all hardware/software resources in computer, process management of Operating System and user interface.

Ability objects: apply theory to practice; learn how to use the structure and design method of Operating System to solve practical problem; construct a foundation for further study database system, computer network, distributed system and other related courses.

Quality objects: master basic system software development methods; provide necessary software design skills for future research and development working.

\section{B. Knowledge points}

Basic working principles of computer Operating System, main functions and implementation methods; operation principle and mechanism of multi-user, multi-tasking operating system; strategy and method of system resource management; user interface of operating system; parallel technology and virtual technology.

\section{Difficult points}

Process management and storage management of operating system; apply theoretical knowledge to practical software or system development. 


\section{Content distribution}

The organizational arrangement of teaching contents, structure and class hours of the Principle and Application of Operating System is shown in table 1 and table 2:

TABLE I. CLASS HOURS DISTRIBUTION

\begin{tabular}{|c|c|c|}
\hline Knowledge Domain & Knowledge Unit & Class Hours \\
\hline \multirow{6}{*}{$\begin{array}{l}\text { The Principle and Application of Operating System (OS) } \\
\text { ( Minimum class hour: } 48 \text { ) }\end{array}$} & Introduction & 4 \\
\hline & Working principle of OS & 6 \\
\hline & Concurrency & 12 \\
\hline & Storage management & 10 \\
\hline & Equipment management & 8 \\
\hline & File system & 8 \\
\hline
\end{tabular}

TABLE II. COURSE CONTENT DISTRIBUTION

\begin{tabular}{|c|c|c|}
\hline Knowledge Unit & Knowledge Point & Learning Target \\
\hline OS1 Introduction & 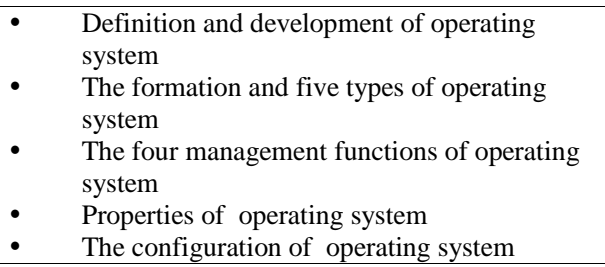 & $\begin{array}{l}\text { - } \quad \text { Master concepts of operating system } \\
\text { - Understand classification and function of operating } \\
\text { system } \\
\text { Master the installation, use and maintenance of } \\
\text { typical operating system } \\
\text { - Understand the structure of the operating system }\end{array}$ \\
\hline $\begin{array}{l}\text { OS2 Working principle of } \\
\text { OS }\end{array}$ & $\begin{array}{l}\text { - } \\
\text { - } \quad \text { Devel, module structure of operating system } \\
\text { - } \quad \text { Thstem development characteristics of human- } \\
\text { - } \quad \text { computer interaction interface } \\
\text { - } \quad \text { Shell language } \\
\text { - } \quad \text { Job scheduling algorithm }\end{array}$ & $\begin{array}{l}\text { - Understand the basic design ideas and methods of } \\
\text { modern computer operating system } \\
\text { Master the basic design idea of man-machine } \\
\text { interface of operating system } \\
\text { - Understand characteristics of traditional interface of } \\
\text { operating system }\end{array}$ \\
\hline OS3 Concurrency & $\begin{array}{ll}\text { - } & \text { Process concept } \\
\text { - } & \text { Concurrency and parallelism of process } \\
\text { - } & \text { Process scheduling algorithm } \\
\text { - } & \text { Process synchronization and mutex } \\
\text { - } & \text { Process PV operation } \\
\text { - } & \text { Deadlock }\end{array}$ & $\begin{array}{l}\text { - } \quad \text { Master the basic concepts of process } \\
\text { Master the basic transformation status and } \\
\text { application characteristics of process } \\
\text { Understand programming technologies of process } \\
\text { scheduling algorithm }\end{array}$ \\
\hline OS4 Storage management & $\begin{array}{ll} & \text { Memory partitioning, paging, and segmenting } \\
\text { management } \\
\text { - } & \text { Physical address and logical address } \\
\text { - } & \text { Virtual memory } \\
\text { - } & \text { Page storage management } \\
\end{array}$ & $\begin{array}{l}\text { - } \\
\text { memorter basic allocation and scheduling algorithms in } \\
\text { - } \\
\text { Master partitions, pagination, segmentation methods }\end{array}$ \\
\hline $\begin{array}{l}\text { OS5 Equipment } \\
\text { management }\end{array}$ & $\begin{array}{l}\text { Functions and classifications of input and } \\
\text { output device } \\
\text { Management features of the exclusive, shared } \\
\text { and virtual device } \\
\text { Management strategy of input and output } \\
\text { device }\end{array}$ & $\begin{array}{l}\text { Master the management characteristics of input and } \\
\text { output device } \\
\text { Master the classification design methods of input and } \\
\text { output device }\end{array}$ \\
\hline OS6 File system & $\begin{array}{ll}\text { - } & \text { File management function } \\
\text { - } & \text { Structure and classification of file } \\
\text { The physical structure and logical structure of } \\
\text { - } & \text { file } \\
\text { - } & \text { Bile directory structure } \\
\text { - } & \text { File security mechanism }\end{array}$ & $\begin{array}{l}\text { - } \quad \text { Master basic file access management methods } \\
\text { Master the directory classification management } \\
\text { characteristics of file system }\end{array}$ \\
\hline
\end{tabular}




\section{CONSTRUCTION SCHEME}

In this section, we will discuss construction scheme of "The Principle and Application of Operating System" from four aspects: teaching mode reform, course construction, course resource and course evaluation.

\section{A. Teaching mode reform}

We construct this excellent shared course for promoting capacity, quality and innovative thinking of students. Thus, our course construction aim is optimizing teaching contents, reforming teaching methods and innovating teaching means.

1) Change idea, face future, and update teaching contents dynamically

Update syllabus, establish curriculum standards, strengthen the coordinated development of knowledge, ability and quality, and embody the idea and direction of modern education.

On the basis of long-term teaching accumulation, we have written teaching textbook "Computer Operating System Training Course" for improving auxiliary teaching materials.

On the selection and construction of content, our course frame adopts the basic theory and basic knowledge of operating system. Our course center is how to apply implementation strategy of computer operating system to solving practical problems. Meanwhile we also show the latest development of modern operating system.

2) People oriented, and attach importance to student's major position

In the aspects of method, organization form and effect evaluation, the course teaching design pays special attention to the students' study subject status [3]. First, the teachers design practical application case, and then by the self-study, group discussion, role playing and student evaluation, the students will actively explore the working principles of operating system and management methods of system resources. In this way, students are passive and active, and the teachers mainly play the role of guiding, commenting and summarizing.

3) Reform teaching methods and means, and cultivate students' comprehensive ability

In order to make the course more suitable for the modern world, all courses have electronic slides and electronic teaching plans. For embodying the idea of teacher leading and student subject, we adopt the problem-centered teaching method. This encourages students to actively participate in various practical situations and interact in time. Students learn about the response and requirements of service objects in their own experience. It enhances students' self-confidence, interpersonal skills and the ability to improvise [4]. In the teaching of twoway interaction between teacher and student, it arouses students' critical consciousness, encourages students to take the initiative to question and cultivates students' innovative thinking ability.

\section{4) Implement " Computational Thinking " oriented course teaching reform \\ Because practical teaching and theoretical teaching of} operating system are difficult to combine effectively, we propose to apply computational thinking to the experimental teaching of operating system curriculum: by adjusting the experimental teaching objectives and making an experimental teaching program centered on computational thinking, it can improve the experimental teaching effect and course teaching quality [5-6].

5) Try to apply MOOCs, invert and mixing class to course teaching reform

By online learning and offline flipped, mixed classroom, we try to apply MOOCs to course teaching reform. It will promote that teachers change their teaching idea, update teaching concepts, innovate teaching methods and further improve their education level and quality.

\section{B. Course construction}

This course adopts the construction ideas of continuously constructing and updating, and gradually transforming into resource sharing course. By updating course resources dynamically, optimizing teaching team continuously and exploring teaching reform methods, we can achieve the goal of building high-quality excellent resource sharing course.

\section{1) Dynamically update course resources}

Since the school opened this course in 2000, the course team has been continuously building, improving and updating the teaching resources of the course. At present, our course team has completed the development of guidance documents such as the knowledge system, curriculum system, syllabus, experimental syllabus, experimental curriculum design scheme, teaching plan schedule, etc. At the same time, we also completed the construction of supporting digital resources such as PPT, exercises and answers, and experimental instructions. And we have written and published a textbook of "Computer Operating System Training Course" for the use and reference of applied colleges and universities. Now,our course team has completed the recording of course contents, including: operating system overview, four management functions of operating system and the core knowledge points of Linux system. It basically includes the complete knowledge system required for the course teaching.

\section{2) Continuously optimize course teaching team}

Having a high-quality teacher team is the cornerstone of career development. Without high-quality teachers, course construction and discipline development can't be discussed. Our course team has taken various approaches, such as "sending out" and "inviting in", to continuously improve the comprehensive quality and ability of teachers. Send out: actively encourage the team teachers to study in the key universities at home and abroad, to train in research institutions or enterprises, and to participate in academic conferences at home and abroad. Invite in: invite famous scholars, business executives and technical directors from home and abroad to give special lectures, provide more opportunities for teachers to contact with domestic and foreign counterparts and enterprises, 
strengthen communication, and achieve the goal of training and cultivating the comprehensive quality of team teachers.

\section{3) Actively explore teaching reform methods}

Bravely reform, strive to develop, integrate modern education concept, and continuously explore teaching innovation means. Now, our course team has applied the MOOCs teaching method to the practical teaching. By combining online learning and offline flipped classroom, it can promote the transformation of teachers' teaching concepts, updating of teaching contents, reforming of teaching methods, and further improve teachers' education quality.

\section{Course resource}

In the aspect of course resources construction, it breaks the traditional single paper textbook resource, makes full use of multi-media resources, and attaches importance to the construction of teacher resources.

\section{1) Textbook is no longer the only resource}

Although the textbook is still the important course resource, but it is no longer the only curriculum resource. Now, we especially emphasize "use textbook to teach", and try to construct reasonable function and structure of course resource for adapting to the modern society diversified demand. This is mainly reflected in the diversity of reference materials and teaching forms. In addition to the traditional paper textbooks, there are various kinds of network resources and classic cases. Thus, after years of careful preparation, the course teaching team has accumulated the rich teaching material. And we have established the school course resources sharing website, recorded corresponding network course. So our online course resources are abundant.

\section{2) Multimedia resources are rich and diverse}

The course resources uploaded to campus website are mainly composed of teaching plans, PPT, experimental instructions and problem sets. In the future, we plan to set up teaching prompt, real-time teaching, discussion communication, q\&a and homework\&exam, etc., to show the related teaching content and process from different angles. In order to arouse students' learning enthusiasm and deepen their perceptual cognition, the teachers in the course group used Dreamweaver and Photoshop to make the contents of the sections with pictures, music and video. These pages are rich in media presentation, bright in color and prominent in key points.

\section{3) Online MOOCs and offline teaching means innovation}

The MOOCs teaching method is carried out in the practical teaching of teachers and students. By combining with online learning and offline flipped and mixed classroom, it can promote the change of teachers' teaching concepts, update teaching contents and teaching methods, and further improve education teaching level and quality.
4) Pay attention to the development and utilization of "teacher" resources

Teachers are the most important resource of the curriculum resource, and the teacher's knowledge level and quality determine the identification range, exploitation and utilization of course resources and the level of benefits. Teachers can make full use of existing resources to realize the maximum value of course resources in the case of shortage of curriculum resources. Therefore, during the construction of course resources, we attach great importance to the construction of teacher. By inviting senior teachers, industry experts, enterprise tutor teaching and research of lectures, we encourage teachers to actively take part in all kinds of continue education activities, academic lectures, etc., for improving their teaching level and overall quality.

\section{Course evaluation}

Hankou University teaching steering committee, supervision and experts unanimously agreed that: after years of construction and development, "The Principle and Application of Operating System" excellent sharing course has formed a united innovative teaching team which has a reasonable age, job title, and education structure. The curriculum standard conforms to the requirements of the computer advanced applied talents training target. In the process of course construction, course team always insists that the students are the center of construction. Thus, we scientifically arrange various teaching activities, make full use of case teaching, and adopt collaborative problem teaching method and online MOOCs teaching means, etc. This can ensure the effectiveness, advancement and innovation of the course teaching. At the same time, our course teaching team pays attention to cultivate students' innovative thinking, practical ability and the team cooperation spirit. After several years of practical teaching, the teaching quality and teaching effect is obvious, and all of our course team teachers get the unanimous approval from our students and our peers.

\section{CONCLUSION}

"The Principle and Application of Operating System" is the basic course of computer science major. It is difficult to learn and teach. This paper discusses the construction scheme of the high-quality resources sharing course "The Principle and Application of Operating System". First, according to the course standards of computer application-oriented talent training program, we write teaching plans and make PPT. Then, we reform the teaching methods and means. Through selfstudy, group discussion, problem driven, online MOOCs learning, it makes students participate in teaching actively, bravely explore problem solving methods, and effectively helps them become the leading character in study. Finally, we build a course resource learning website. Through online learning and offline guidance, it can effectively arouse the enthusiasm of students' autonomous learning and promote the interaction between teachers and students. Eventually, it improves the teaching effect and quality and resolves the problem of hard to study and teach. 


\section{ACKNOWLEDGMENT}

This study is supported by 2015 Hubei university provincial high-quality resource sharing course undergraduate course project (File number: Hubei high education letter [2016] No.5).

\section{REFERENCES}

[1] Pang Liping, The Principle of Operating System [M]. Wuhan: Huazhong University of Science \& Technology Press, 2008. (In Chinese)

[2] Yin Yanju. Computer Application Training Program. http://wenku.baidu.c, 2016. (In Chinese)

[3] Ye Junmin, Li Yuan. Teaching of the Principles of Operating System between Practice and Theory [J], Experimental Technology and Management, 2010, vol.27 (9), pp. 171- 173. (In Chinese)

[4] Pu Xiaorong, Ren Liyong. Research Teaching and Learning OS by Integrating Theory with Practice [J], Experiment Science and Techology, 2011, vol.9(5), pp. 233-235+252. (In Chinese)

[5] Wing J M. Computational Thinking [J]. Communications of the ACM,2006, vol.49(3), pp. 33-35.

[6] Li Qiong, Chen Li. Research on the Course Teaching of Operating System Based on Computational Thinking [J]. Computer CD Software And Applications, 2014, vol.17(12), pp. 231-232. (In Chinese) 